\title{
A review of the epidemiology and control of gastrointestinal nematode infections in cattle in Zimbabwe
}

\begin{tabular}{|c|c|}
\hline \multicolumn{2}{|c|}{$\begin{array}{l}\text { Davies M. Pfukenyi }{ }^{1} \\
\text { Samson Mukaratirwa }^{1}\end{array}$} \\
\hline \multicolumn{2}{|c|}{$\begin{array}{l}\text { Affiliations: } \\
{ }^{1} \text { Biodiversity/Evolutionary } \\
\text { Biology Group, School of } \\
\text { Life Sciences, University of } \\
\text { KwaZulu-Natal, Westville } \\
\text { campus, South Africa }\end{array}$} \\
\hline \multicolumn{2}{|c|}{$\begin{array}{l}\text { Correspondence to: } \\
\text { Samson Mukaratirwa }\end{array}$} \\
\hline \multicolumn{2}{|c|}{$\begin{array}{l}\text { Email: } \\
\text { mukaratirwa@ukzn.ac.za }\end{array}$} \\
\hline \multicolumn{2}{|c|}{$\begin{array}{l}\text { Postal address: } \\
\text { School of Life Sciences, } \\
\text { University of KwaZulu-Nat } \\
\text { Private Bag X54001, Durb } \\
4001 \text {, South Africa }\end{array}$} \\
\hline \multicolumn{2}{|c|}{$\begin{array}{l}\text { Dates: } \\
\text { Received: } 29 \text { Apr. } 2013 \\
\text { Accepted: } 26 \text { June } 2013 \\
\text { Published: } 19 \text { Aug. } 2013\end{array}$} \\
\hline \multicolumn{2}{|c|}{$\begin{array}{l}\text { How to cite this article: } \\
\text { Pfukenyi, D.M. \& } \\
\text { Mukaratirwa, S., } \\
2013 \text {, 'A review of the } \\
\text { epidemiology and control of } \\
\text { gastrointestinal nematode } \\
\text { infections in cattle in } \\
\text { Zimbabwe', Onderstepoort } \\
\text { Journal of Veterinary } \\
\text { Research } 80(1), \text { Art. \#612, } \\
12 \text { pages. http://dx.doi. } \\
\text { org/10.4102/ojvr.v80i1.612 }\end{array}$} \\
\hline \multicolumn{2}{|c|}{$\begin{array}{l}\text { Copyright: } \\
\text { (C) 2013. The Authors. } \\
\text { Licensee: AOSIS } \\
\text { OpenJournals. This wC } \\
\text { is licensed under the } \\
\text { Creative Commons } \\
\text { Attribution License. }\end{array}$} \\
\hline \multicolumn{2}{|l|}{ Read online: } \\
\hline 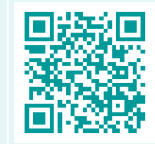 & $\begin{array}{l}\text { Scan this QR } \\
\text { code with your } \\
\text { smart phone or } \\
\text { mobile device } \\
\text { to read online. }\end{array}$ \\
\hline
\end{tabular}

In this review, the main gastrointestinal nematodes infecting cattle in Zimbabwe and the epidemiological factors influencing their occurrence are reviewed and discussed. Nineteen gastrointestinal nematode species that belong to seven families have been found to occur in cattle in Zimbabwe. The main genera reported to date are Cooperia, Haemonchus, Trichostrongylus and Oesophagostomum and the dominant species are Cooperia pectinata, Cooperia punctata, Haemonchus placei and Trichostrongylus axei. The mixed infection by several species from the genera is the cause of parasitic gastroenteritis in cattle in Zimbabwe. Production and husbandry practices, season, host age and environment are considered to be the main factors that influence gastrointestinal nematode infection in cattle. The geographical distribution of the gastrointestinal nematodes is also reviewed in relation to the climatic conditions of the country. Various control options are discussed and how they are applicable to the Zimbabwean situation. Based on reports and existing data on the epidemiological features of the gastrointestinal nematode infection in cattle, practical control measures are critically reviewed and recommendations are made for a national control programme.

\section{Introduction}

Gastrointestinal (GI) nematode infections of cattle are constraints on the efficient raising of cattle on pasture throughout the world (Gasbarre, Leighton \& Sonstergard 2001). These parasites have two main features of epidemiological importance: there is no multiplication of their preparasitic stages and their infective stages, whether acquired directly by the host or indirectly via intermediate hosts, always give rise to a single adult male or female parasite in the definitive host (Chiejina 1994). Therefore, the number of infective stages present in the host environment at any given period is related to the number of worm eggs passed by the host and this largely determines the number of parasites potentially capable of being established in a susceptible host. However, characteristics such as breed, age and nutritional status of the host as well as characteristics of the environment also have a considerable influence on the parasites and their capacity to infect and inflict damage to the host (Rivera et al. 1983). Most studies on GI nematode ecology in cattle have concluded that climatic conditions play an important role in the survival and transmission of parasite eggs and larvae (Rivera et al. 1983). Therefore, to be effective, control measures depend on a sound understanding of the epidemiology of the disease in both the host and the environment. In this review, the information on the epidemiology of GI nematodes of cattle reported to date in Zimbabwe is presented and the different options recommended for their control are discussed.

\section{Species of nematodes infecting cattle in Zimbabwe}

Gastrointestinal nematodes of cattle have different pathogenic effects (Charlier et al. 2009) and it is important to establish which broad groups are present in a herd, area, country or region. Furthermore, some of these nematodes have different development times and stages outside and inside the definitive host; knowledge of which is important for effective control measures.

Gastrointestinal nematode infections in cattle in Zimbabwe have been reported by various authors (Bryant \& Norval 1985; Pandey 1989; Eysker, Jansen \& Pandey 1990; Pandey, Nyanzunda \& Chitate 1990a; Pandey et al. 1990b; Duncan \& Forbes 1992; Obwolo et al. 1992; Pandey, Chitate \& Nyanzunda 1993; Vassilev 1993, 1994, 1999; Obwolo et al. 1995; Moyo et al. 1996; Moyo et al. 1997; Moyo et al. 2003; Magaya et al. 2000; Pfukenyi et al. 2007) and unpublished records from the State Central Veterinary Research Laboratory, Harare, Zimbabwe. Parasitic gastroenteritis (PGE) in cattle is caused by mixed infections of several nematode species (Table 1). Nineteen GI nematode species belonging to seven families have been reported to infect cattle in Zimbawe (Table 1). 
The most important and widely prevalent nematodes belong to the Family Trichostrongylidae, which is composed of the genera Cooperia, Haemonchus, Trichostrongylus and Ostertagia and to the Family Chabertiidae, which is composed of the genus Oesophagostomum. The genera Bunostomum, Nematodirus, Strongyloides, Toxocara and Trichuris are of lesser frequency (Pandey et al. 1993; Vassilev 1994, 1999; Moyo et al. 1996; Pfukenyi et al. 2007).

\section{Cooperia}

Five Cooperia species have been reported to infect cattle in Zimbabwe (Table 1). Cooperia pectinata, Cooperia punctata and Cooperia spatulata are the most common species in cattle in the tropics (Horak 1981) and as expected they are present in cattle in Zimbabwe (Buckley 1933; Moyo et al. 1996; Magaya et al. 2000). Cooperia pectinata and C. punctata are the most prevalent species and they have been found in both the highveld and lowveld regions of Zimbabwe (Vassilev 1993; Moyo et al. 1996). Cooperia oncophora is mainly found in temperate climates (Shaw et al. 1998) and has been reported only once in Zimbabwe (Buckley 1933). This was most likely a case of misidentification (Jooste 1989) as there have been no other reports within the country since then. However, the parasite was recorded in cattle in the Eastern Cape Province of South Africa (Horak, Evans \& Purnell 2004), which experiences low temperatures similar to the temperate regions of Europe The importation of cattle from Europe could probably explain the presence of the parasite in Zimbabwe. Although it is normally a species of wild ruminants (Jooste 1989; Madzingira \& Mukaratirwa 2002; Madzingira et al. 2002a), Cooperia hungi

TABLE 1: Checklist of gastrointestinal nematode species reported in cattle in Zimbabwe.

\begin{tabular}{lll}
\hline Family & Species & References \\
\hline Ascarididae & Toxocara vitulorum & $4,9,11$ and 13 \\
Ancylostomatidae & Bunostomum phlebotomum & 3 \\
Strongyloididae & Strongyloides papillosus & 8,11 and 13 \\
Chabertiidae & Oesophagostomum radiatum & 3,11 and 14 \\
Trichostrongylidae & Cooperia pectinata & 3,11 and 14 \\
& Cooperia punctata & 8,11 and 14 \\
& Cooperia spatulata & 11 \\
& Cooperia hungi & 8 and 15 \\
& Cooperia oncophora & 3 \\
& Haemonchus placei & 4 and 8 \\
& Haemonchus contortus & 1 and 8 \\
& Haemonchus similis & 8 \\
& Trichostrongylus axei & 8 \\
& Trichostrongylus colubriformis & 11 \\
& Ostertagia ostertagi & 11 and 12 \\
Trichuridae & Nematodirus spp. & 8 and 10 \\
& Trichuris globulosa & 2 and 13 \\
& Trichuris barbertonensis & 8 \\
\hline & Trichuris ovis & 3 \\
\hline
\end{tabular}

Note: Please see the full reference list of this article: Pfukenyi, D.M. \& Mukaratirwa, S., 2013 'A review of the epidemiology and control of gastrointestinal nematode infections in cattle in Zimbabwe', Onderstepoort Journal of Veterinary Research 80(1), Art. \#612, 12 pages. doi:10.4102/ojvr.v80i1.612, for more information.

1, Bevan (1929); 2, Bevan (1930); 3, Buckley (1933); 4, LeRoux (1957); 5, Grant (1973); 6 Jooste (1984); 7, Jooste (1987); 8, Jooste (1989); 9, Pandey et al. (1990b); 10, Obwolo et al. (1992); 11, Moyo et al. (1996); 12, Moyo et al. (1997); 13, Vassilev (1999); 14, Magaya et al. (2000); 15, Madzingira et al. (2002b). has also been reported in cattle (Jooste 1989). This could have been caused by cross-transmission from wild ruminants in cattle-antelope mixed farming systems (Madzingira \& Mukaratirwa 2002).

\section{Haemonchus}

Three Haemonchus species have been recorded (Table 1). Haemonchus placei is the most prevalent species and has been found in both the highveld and lowveld regions of Zimbabwe (Vassilev 1993; Obwolo et al. 1995; Moyo et al. 1996, 2003; Magaya et al. 2000; Moyo 2006). In contrast, Haemonchus similis and Haemonchus contortus have been found mainly in the highveld region (Madzingira et al. 2002a). Both H. placei and $H$. similis are more adapted to cattle, whilst $H$. contortus is more adapted to sheep and goats (Amarante et al. 1997). Thus, cross-infection of the Haemonchus species between sheep, goats and cattle and of $H$. contortus between cattle and some antelopes (Madzingira et al. 2002a) has seemed to occur in Zimbabwe and this should be taken into consideration when formulating control measures.

\section{Trichostrongylus}

Two Trichostrongylus species have been reported (Table 1). The most frequent species is Trichostrongylus axei; there are a few reports of Trichostrongylus colubriformis (Moyo et al. 1996; Moyo 2006). Few reports of T. colubriformis in cattle in South Africa are available (Horak 1981; Horak et al. 2004). Trichostrongylus colubriformis is a parasite of sheep and its presence in cattle is likely to be due to cross-infection (Horak et al. 2004). However, with the exception of T. axei, parasite species belonging to the Trichostrongylus genus are not considered to be important in cattle (Horak et al. 2004).

\section{Trichuris}

The prevalence of infection with the Trichuris species in cattle is generally low, with Trichuris globulosa being the most frequently encountered (Vassilev 1999). Trichuris barbertonensis (Jooste 1989) and Trichuris ovis (Buckley 1933) have been reported once in cattle, and according to Jooste (1989) the presence of T. ovis in cattle was a misidentification. Trichuris barbertonensis was also documented in goats and other wild ruminants such as impala (Aepyceros melampus), steenbuck (Raphicerus campestris) and buffalo (Syncerus caffer) (Table 2).

\section{Other genera}

The other minor parasite species in terms of severity and prevalence of infection are from the genera Bunostomum, Nematodirus, Oesophagostomum, Ostertagia, Toxocara and Strongyloides (Table 1). Except in calves in the high-rainfall highveld region, Bunostomum phlebotomum has been found in low numbers (Moyo et al. 1996). Similarly, the prevalence of Oesophagostomum radiatum and Toxocara vitulorum has been found to be low (Moyo et al. 1996; Pfukenyi et al. 
2007). As expected, infection with Strongyloides papillosus is confined to calves less than eight months of age due to their immature immune status (Pandey et al. 1993; Vassilev 1999; Moyo et al. 1996; Pfukenyi et al. 2007). Ostertagia ostertagi (Moyo et al. 1996) and Nematodirus species (Obwolo et al. 1992) have been reported on an irrigated farm and a communal farming area in the highveld region, respectively. Jooste (1989) also reported Nematodirus species in cattle, but the origin of the animals was not given. Nematodirus filicolis (Lawrence 1928) and Ostertagia circumcincta (Christe 1957) were also documented once in sheep. However, Jooste (1989) indicated that the reports could have been misidentification.

\section{Survival of free-living stages in the environment}

Cooperia pectinata and C. punctata and to a lesser extent Cooperia spatulata, H. placei and T. axei are the dominant species infecting cattle in Zimbabwe with the Cooperia species being the most prevalent (Pandey et al. 1993; Moyo et al. 1996; Vassilev 1999; Pfukenyi et al. 2007). Free-living stages of nematode parasites of grazing animals differ in their responses to environmental conditions - notably temperature and moisture - these differences exist within and between nematode species (Chiejina 1994). The larvae of C. pectinata are well adapted to extremes of heat, cold and to dry conditions (Reinecke 1960; Durie 1962; Lima 1998). They survive and persist longer and migrate better than the other nematodes (Reinecke 1960). Studies in Zimbabwe (Moyo et al. 1996; Pfukenyi et al. 2007) have also indicated that

TABLE 2: Checklist of cattle gastrointestinal nematode species reported in other domestic and wild ruminants in Zimbabwe.

\begin{tabular}{|c|c|c|}
\hline Nematode species & Ruminant species & References \\
\hline $\begin{array}{l}\text { Bunostomum } \\
\text { phlebotomum }\end{array}$ & $\begin{array}{l}\text { Blue wildebeest (Connochaetes } \\
\text { taurinus) }\end{array}$ & 8 \\
\hline Cooperia pectinata & $\begin{array}{l}\text { Sheep (Ovis aries), Impala } \\
\text { (Aepyceros melampus), Tsessebe } \\
\text { (Damaliscus lunatus), Sable } \\
\text { antelope (Hippotragus niger), } \\
\text { Buffalo (Syncerus caffer), Eland } \\
\text { (Taurotragus oryx), Kudu } \\
\text { (Tragelaphus strepsiceros) }\end{array}$ & $5,7,8$ and 15 \\
\hline Cooperia punctata & $\begin{array}{l}\text { Sheep, Sable antelope, Sharpe's } \\
\text { Grysbok (Raphicerus sharpei), } \\
\text { Buffalo, Kudu }\end{array}$ & 5,8 and 15 \\
\hline Cooperia spatulata & Sheep & 5 \\
\hline Haemonchus placei & Kudu & 8 \\
\hline Haemonchus similis & Tsessebe, Sable antelope & 8 \\
\hline $\begin{array}{l}\text { Oesophagostomum } \\
\text { radiatum }\end{array}$ & Eland & 8 \\
\hline Strongyloides papillosus & $\begin{array}{l}\text { Sheep, Impala, Common duiker } \\
\text { (Sylvicapra grimmia) }\end{array}$ & 3,7 and 15 \\
\hline Trichostrongylus axei & $\begin{array}{l}\text { Sheep, Blue duiker (Cephalophus } \\
\text { monticola), Roan antelope } \\
\text { (Hippotragus equinus), Sable } \\
\text { antelope, Sharpe's Grysbok }\end{array}$ & 4,6 and 8 \\
\hline Trichuris globulosa & $\begin{array}{l}\text { Sheep, Goat (Capra hircus), } \\
\text { Impala, Roan antelope, Sable } \\
\text { antelope, Waterbuck (Kobus } \\
\text { ellipsiprymnus), Sharpe's Grysbok }\end{array}$ & 7 and 8 \\
\hline Trichuris barbertonensis & $\begin{array}{l}\text { Goat, Impala, Steenbuck } \\
\text { (Raphicerus campestris), Buffalo }\end{array}$ & 7,8 and 15 \\
\hline
\end{tabular}

Note: Please see the full reference list of this article: Pfukenyi, D.M. \& Mukaratirwa, S., 2013, 'A review of the epidemiology and control of gastrointestinal nematode infections in cattle in Zimbabwe', Onderstepoort Journal of Veterinary Research 80(1), Art. \#612, 12 pages. doi:10.4102/ojvr.v80i1.612, for more information.

1, Bevan (1929); 2, Bevan (1930); 3, Buckley (1933); 4, LeRoux (1957); 5, Grant (1973); 6 Jooste (1984); 7, Jooste (1987); 8, Jooste (1989); 9, Pandey et al. (1990b); 10, Obwolo et al. (1992); 11, Moyo et al. (1996); 12, Moyo et al. (1997); 13, Vassilev (1999); 14, Magaya et al. (2000); 15, Madzingira et al. (2002b).
Cooperia third-stage larvae $\left(\mathrm{L}_{3}\right)$ are more resistant to adverse conditions like high temperature and dryness, as high numbers of larvae were observed during both the wet and dry seasons. These findings probably explain the predominance of the Cooperia species. The lower prevalence of H. placei when compared to the Cooperia species could probably be attributed to the $\mathrm{L}_{3}$ being more sensitive to hot, arid conditions and shorter survival periods (Reinecke 1960). In support of this, a significantly higher prevalence of Haemonchus species was observed during the wet months of the year than during the dry season and in the high-rainfall highveld regions than the drier lowveld regions (Vassilev 1994; Pfukenyi et al. 2007). However, the lower prevalence during the dry season could be attributed to hypobiosis, which is shown to occur in the highveld region during the same period each year (Moyo et al. 1996; Magaya et al. 2000). The relatively low to moderate prevalence of Trichostrongylus species when compared to Cooperia and Haemonchus species could probably be attributed to the fact that lower temperatures are required for the development of its freeliving stages (Levine 1963; Williams \& Mayhew 1967; Lima 1998). Higher monthly percent frequency of infective larvae of the Trichostrongylus species was observed during the cold dry months (May to August) in Zimbabwe (Pfukenyi et al. 2007).

The survival rate and migration of $O$. radiatum is lower in comparison to the Cooperia species and H. placei (Reinecke 1960). Its low prevalence is attributed to its relatively long life cycle and low resistance to desiccation during its preinfective stages (Rivera et al. 1983). Immunity may also play an important role in the differences noted; $O$. radiatum is extremely effective in eliciting strong, protective immune responses. A primary exposure of previously naïve animals to infection or even to parasite antigens results in a very significant reduction in the number of parasites that can become established after a subsequent infection (Gasbarre \& Canals 1989). As a result, these parasites remain largely a problem for only young animals in the herd (Gasbarre \& Canals 1989), a finding that is consistent with observations in Zimbabwe (Moyo et al. 1996; Pfukenyi et al. 2007). However, other parasites such as the Cooperia species and H. placei require a longer period of exposure before this level of protective immunity is seen (Gasbarre \& Canals 1989).

The survival of B. phlebotomum is extremely low compared to other nematode species and is only present in large numbers when well-distributed summer rainfall provides adequate moisture for larval development and survival (Reinecke 1960). In addition, the possibility of infection, especially under extensive range-type operations with low animal density, is greatly reduced since the larvae do not migrate from the faeces, but penetrate the host's skin (Reinecke 1960; Rivera et al. 1983). Its occurrence in Zimbabwe is sporadic and tends to be localised, favouring soils with high moisture content; this can be a problem in Kalahari sandveld areas of the country (Jooste 1987). 
Toxocara vitulorum is an infrequent parasite under extensive farming conditions (Bianchin \& Honer 1987). Its prevalence is low in communal and on commercial farms where cattle are kept under extensive farming conditions (Moyo et al. 1996; Pfukenyi et al. 2007). However, its prevalence in calves on irrigated farms in the highveld region has been found to be high (Pandey et al. 1990b; Moyo et al. 1996). According to Pandey et al. (1990b), under natural conditions T. vitulorum infection is low and the high prevalence that has been observed on irrigated farms is due to the unique system of farm management resulting in persistent moist or wet pastures. However, lactogenic transmission is an important source of infection to calves and the larvae are present in milk for up to three to four weeks after parturition (Pandey et al. 1990b). In cows, resumption of larval development in late pregnancy allows further lactogenic transmission.

Tropical climates do not offer favourable conditions for the transmission and survival of Ostertagia and Nematodirus species (Levine 1963), so both parasites are of little significance in Zimbabwe. However, Nematodirus helvetianus occurs in calves in the moist, temperate climates of the coastal provinces (Eastern Cape, Western Cape and KwaZulu-Natal) of South Africa (Reinecke 1983; Horak et al. 2004). Similarly, O. ostertagi has been reported in cattle on coastal pastures in the Eastern Cape Province of South Africa. However, the parasite species also occurs in cattle in the non-coastal areas of the eastern highveld of Mpumalanga Province (Louw 1999) and the northeastern highveld of the Free State Province (Tsotetsi \& Mbati 2003) in South Africa. The presence of these parasites in Zimbabwe could probably be attributed to importation of cattle from South Africa.

Table 2 shows GI nematodes reported in cattle that were also documented in other domestic and wild ruminants in Zimbabwe. The data show that C. pectinata, C. punctata, $H$. similis, S. papillosus, T. axei, T. globulosa and T. barbertonensis were found in at least two other domestic or wild ruminants, whilst the others were reported in only one other domestic and/or wild ruminant. These findings are important when considering different options for the control of these parasites in cattle.

\section{Factors influencing gastrointestinal nematode infection in cattle}

\section{Season and host-age}

When cattle graze on natural pastures, climate plays an important role in the transmission of GI nematodes (Gatongi, Gathuma \& Munyua 1987). The climate in Zimbabwe is characterised by a warm wet season from November and December to March and April, followed by a cool dry season (May to August) and later a hot dry period (September to October and November). The general trend of GI nematode faecal egg counts (FECs) is related to the rainfall pattern (Obwolo et al. 1992; Eysker et al. 1990; Pandey et al. 1993; Vassilev, 1994, 1999; Moyo et al. 1996; Pfukenyi et al. 2007).
Faecal egg counts (FECs) rise from November and December to reach a peak during March and April, followed by a decline to low levels during the dry period from May and June to October and November (Pandey et al. 1993; Vassilev, 1994, 1999; Moyo et al. 1996; Pfukenyi et al. 2007). Similarly, the population of infective larvae on pastures increases to a maximum during the rainy season, which coincides with the peak in FECs (Pandey 1989; Eysker \& Pandey 1991; Vassilev 1993; Moyo et al. 1996, Moyo et al. 1997). Pasture larval counts are generally low during the dry season, with the population of infective larvae on pastures being negligible between June and October. However, an important observation is that although pasture infectivity decreases during the dry season, some larvae can be found on pasture throughout the dry season, particularly on farms with irrigated pastures (Moyo et al. 1996).

Thus, during the rainy season (December to March), the rainfall and temperature are favourable for the development, survival and translation of infective larvae on herbage. These conditions result in increased availability of infective larvae on pastures, so the chances of cattle picking up infective stages of the parasites whilst grazing are high, leading to a buildup of high worm burdens in the host. This leads to an increase in FECs with peaks between February and March and April and May. During late autumn to early spring (May to October and November) the decline in FECs is due to lack of rainfall and to some extent lower and higher temperatures; these are conditions that are unfavourable for the development of eggs into infective larvae. Hence, the wet months carry the highest risk of occurrence of parasitic gastroenteritis (PGE) in cattle; therefore control measures should take this factor into consideration. However, it is also important to note that the most pathogenic GI nematode parasites, Haemonchus species, survive the dry season as inhibited early fourth-stage larvae (hypobiosis), whereas the other species from the genera Cooperia and Trichostrongylus survive the dry season mainly as adults (Moyo et al. 1996; Magaya et al. 2000).

The prevalence of GI nematodes as observed through faecal egg counts is higher in animals aged less than 12 months as opposed to adult cattle (Pfukenyi et al. 2007). Hence, adult cattle act as reservoirs of infection and constant sources of infection for the more susceptible young animals. A higher prevalence and egg count of GI nematodes was demonstrated in lactating and pregnant cows when compared to dry cows, bulls and oxen; this confirms the periparturient eggrise phenomenon (Pfukenyi et al. 2007) and thus serves as a source of pasture contamination.

\section{Production and husbandry practices}

Just as meteorological and other environmental factors largely determine the overall number of infective stages of nematode parasites at any given time, livestock husbandry systems and management practices have a major influence on the transmission of that infection to a susceptible host population (Chiejina 1994). The methods of cattle management in Zimbabwe are varied and are inextricably 
linked with systems of agricultural production as well as with local traditions and beliefs. However, the main husbandry systems are communal or rural, small-scale holder and commercial. Mixed farming systems of cattle and game, particularly antelopes, were introduced on cattle ranches in the nineties and have become an important agricultural activity in Zimbabwe (Knottenbelt 1990; Madzingira et al. 2002b).

There are contradictory results on GI nematode infections in cattle on communal land. Earlier studies reported low levels of infection leading to the conclusion that GI nematodes were of no importance and do not contribute significantly to the poor body condition and low productivity recorded in cattle (Bryant \& Norval 1985; Pandey et al. 1990a; Obwolo et al. 1992). However, later studies (Pandey et al. 1993; Vassilev 1994; 1999; Moyo et al. 1996; Pfukenyi et al. 2007) showed high levels of GI nematode infections in communal cattle. The levels of infection, particularly during the rainy season, could vary depending on farming systems (Moyo et al. 1996). Faecal egg, pasture larval and worm counts were highest in communally-grazed cattle, intermediate in cattle on irrigated commercial farms and lowest in cattle on conventional commercial farms (Moyo et al. 1996). These differences could be due to different management systems and different microclimatic conditions. Communal cattle are kept under extensive free-range poor communal pastures with very little input of feed supplements. Anthelmintic $(\mathrm{AH})$ treatment of communal cattle is either non-existent or very occasional and irregular and, if given at all, is limited to a few sickly animals (Pandey et al. 1993). In addition, the stocking rate is high, being estimated to be 0.37 livestock units per hectare; this may be increased more than two-fold during the rainy season as $50 \%-60 \%$ of the land is used for growing crops during that period (Pandey et al. 1993). Thus, a combination of poor nutrition, overgrazing, high stocking rate and lack of $\mathrm{AH}$ medication results in heavy worm burdens in communally grazed cattle (Pandey et al. 1993) compared to others. In contrast, cattle on conventional commercial farms are kept under modern extensive or intensive conditions where stocking rates are lower, particularly in the hot and dry lowveld region (Moyo et al. 1996). In addition, commercial farmers tend to treat all animals with an $\mathrm{AH}$ at the beginning of the dry season (April to May) and/or the beginning of the rainy season (November to December) (Moyo et al. 1996). Hence, worm burdens in this category of cattle are lower than communally grazed cattle. The obvious reason for higher levels of infection and pasture contamination on irrigated commercial farms when compared to conventional commercial farms is the higher stocking rate that is allowed by the irrigation and furthermore, irrigation implies an increase of the length of infectivity of pasture as shown by higher pasture larval counts (Moyo et al. 1996).

In mixed cattle-game farming systems, cattle and game species, particularly antelopes, are reared together. Mixed farming with cattle and antelope is attributed to bring about the possibility of cross-infection of helminth parasites
(Jooste 1987; Knottenbelt 1989; Madzingira et al. 2002a). A high stocking density of antelope and domestic ruminants is known to favour such cross-infection and the random translocation of game may broaden the endemic and host ranges of internal parasites (Horak 1981). Earlier studies in Zimbabwe have shown cross-infections of $H$. contortus, T. axei, T. colubriformis, Dictyocaulus viviparus, C. pectinata and C. punctata from domestic ruminants, including cattle, to antelopes (Condy 1972; Grobler 1981; Jooste 1984, 1987; Knottenbelt 1989, 1990). Later, Madzingira et al. (2002a) reported evidence of cross-infections of $O$. radiatum and S. papillosus from cattle to antelope species. No common helminths of antelope were recovered from cattle, implying that antelopes may act as reservoir hosts of infection for cattle. It appears that antelope are better hosts for helminths of cattle than cattle are for those of antelopes (Horak 1980; Boomker, Du Plessis \& Boomker 1983; Boomker et al. 1984; Madzingira et al. 2002a). Thus, antelopes are more likely to suffer in a mixed farming system with cattle. However, the degree of cross-infection was low and the parasites involved occurred in low numbers, which may have little effect on the health of the antelopes (Madzingira et al. 2002b).

\section{Impact on production}

Infections with GI nematodes in cattle do not necessarily result in disease. However, heavy infections result in clinical PGE and this consequently leads to inappetence, impaired gastrointestinal function and changes in protein, energy, mineral metabolism and water balance (Fox 1993). Clinical PGE is characterised by watery diarrhoea, weight loss or reduced weight gain, dull hair coat, anorexia and a general loss of condition (Anderson et al. 1965). Data on reduced feed intake due to GI nematode infections in cattle are scarce; however, Forbes et al. (2000) observed that cattle treated with the ivermectin sustained-release bolus (IVOMEC ${ }^{\circledR}$ SR Bolus, Merial, USA), on average grazed 105 minutes longer per day than those with evidence of patent nematode infections. Subclinical infections without obvious clinical signs constitute the majority of infections and cause economic losses due to sub-optimal performance (Vercruysse \& Claerebout 2001).

Gastrointestinal nematodes are considered to be primarily important in first season grazing calves in summer (Charlier et al. 2009). Increased weight gain is the most often observed and best-documented benefit of GI nematode control in first season grazing calves (Charlier et al. 2009). This effect on weight gain was studied in relation to anthelmintic treatment in Western Europe (Shaw et al. 1998; Dimander et al. 2000, Dimander 2003; Larsson et al. 2006). Similar studies were conducted in Zimbabwe (Duncan \& Forbes 1992; Vassilev 1993; Magaya et al. 2000; Moyo et al. 2003), which showed a significant effect of anthelmintic treatment on the enhancement of productivity and protection from the effects of infection with nematode parasites in cattle. In the last decade, substantial generated evidence showed that GI nematodes could also have negative impacts on the 
performance of adult cattle (Charlier et al. 2009). The milk yield response to anthelmintic treatment in pastured dairy cows was observed to be around $1 \mathrm{~kg} / \mathrm{cow}$ per day (Charlier et al. 2009). In anthelmintic-treated beef cows, increased conception and calving rates, and reductions in calf mortality and calving-to-breeding intervals were shown (Hawkins 1993; Gross, Ryan \& Ploeger 1999). Similar studies in dairy cows showed shorter calving-to-conception intervals in treated cows when compared to untreated controls (Walsh, Younis \& Morton 1995; Sanchez et al. 2002). However, no such studies have been conducted in Zimbabwe and the impact of GI nematodes on production should be investigated in different categories of cattle.

\section{Control}

The available epidemiological information on GI nematodes of cattle in Zimbabwe was used in this review to design appropriate control measures. Methods available for the control of GI nematode infections are mainly based on chemical treatment, non-chemical management practices, immune modulation and biological control.

\section{Chemical treatment}

The use of anthelmintics is still the mainstay for nematode control. Vercruysse and Claerebout (2001) defined a number of threshold conditions for choosing to treat cattle with an AH drug. A therapeutic threshold is intended to identify animals with parasitic levels that necessitate immediate treatment and is basically the diagnosis of clinical disease. The phenomenon of parasite over-dispersion could be put to good use if those animals suffering from sufficient levels of infection to cause considerable production loss or health effects could be identified and treated individually (Malan, Van Wyk \& Wessels 2001). In the northern hemisphere, cattle PGE is caused by $O$. ostertagi together with Cooperia and Trichostrongylus species and it occurs mainly in first season grazing calves in summer. Similarly, in Zimbabwe and other southern Africa countries, PGE occurs mainly in young cattle in summer, but is mainly due to Haemonchus together with Cooperia and Trichostrongylus species.

The diagnosis of PGE can be based on clinical signs confirmed by FECs or by determination of parasite specific serum antibody, gastrin or pepsinogen levels (Berghen et al. 1993). In New Zealand, the FEC strategy achieved a reduction in the frequency of $\mathrm{AH}$ use (Leathwick et al. 2006). However, the main drawback is that this is impractical in Zimbabwe due to the limitations of cost and facilities and lack of farmers' training on diagnosis of cattle PGE based on clinical signs. The measurement of serum pepsinogen and gastrin levels is a specific tool in the diagnosis of ostertagiosis, which is not important in Zimbabwe and other southern Africa countries since the disease is not common in the region. Similarly, an enzyme-linked-immunoabsorbent-assay (ELISA) specific for the temperate $C$. oncophora has been developed (Poot et al. 1997), but might not be useful for the tropical Cooperia species. However, since the animals that are most susceptible to parasites and/or their effects, and hence require repeated
$\mathrm{AH}$ treatments, are commonly the same within a season or between seasons (Malan, Van Wyk \& Wessels 2001), the therapeutic or targeted (selective) animal treatment remains a beneficial approach. Hence, for the time being, to improve the therapeutic approach in Zimbabwe, simple user-friendly extension material on PGE should be produced and disseminated to farmers and extension staff. For exploitation of the over-dispersion concept, research focused on production of convenient, inexpensive and accurate onfarm methods (e.g., Faffa Malan chart (FAMACHA ${ }^{\odot}$ ) in small ruminants) for identifying animals for targeted selective treatment should be prioritised.

The threshold for production-based treatment is essentially based on the identification of the so-called 'sub-clinical' infections that are characterised by no clinical signs of PGE in untreated animals. However, the level at which GI nematode infection in cattle results in sub-clinical parasitism and any associated production losses has not been defined (Vercruysse \& Claerebout 2001). Useful tools to define subclinical parasitism such as pepsinogen and gastrin levels, serum and milk antibody levels and the coproantigen detection test were evaluated in western Europe for temperate GI nematodes (Hilderson et al. 1992; Kloosterman et al. 1996; Guitian et al. 2000; Agneessens, Vercruysse \& Claerebout 2001). However, these tools have not been assessed for tropical GI nematodes.

GI nematode infections should be prevented rather than cured, with the preventive measures being applied at herd level (Vercruysse \& Claerebout 2001). Based on the current increased knowledge about the epidemiology of GI nematodes in Zimbabwe, preventive treatment strategies of PGE in cattle can be formulated. GI nematode infections in cattle are high during the rainy season and low during the dry season. A strategic treatment should be carried out when pasture infectivity levels are low during the dry season and a tactical treatment at the peak of pasture infectivity levels during the rainy season (Figure 1). The basis of the strategic treatment is to achieve a long-lasting effect on worm burdens so that re-infection during the dry season will be minimal and additionally the negative impacts of a combination of poor nutrition with nematode infections will be prevented (Moyo et al. 2003). The rationale of the tactical treatment is to prevent clinical disease during the peak period of infection.

The broad spectrum $\mathrm{AH}$ that are available in Zimbabwe include: the benzimidazoles (BZ) (albendazole, fenbendazole and oxfendazole); imidazothiazoles (levamisole); macrocyclic lactones (ML) (ivermectin and doramectin); with benzimidazoles being the most commonly used generic drugs. A broad-spectrum $\mathrm{AH}$ administered tactically in January and March (Figure 1) would control immature and adult forms of $H$. placei, O. radiatum, Cooperia species and Trichostrongylus species. However, the timing of tactical treatments depends on several factors and hence no hard and fast rules can be applied for their implementation (Van Wyk 1990). For instance, rainfall over a number of days is more dangerous than a similar amount of rain on a single 


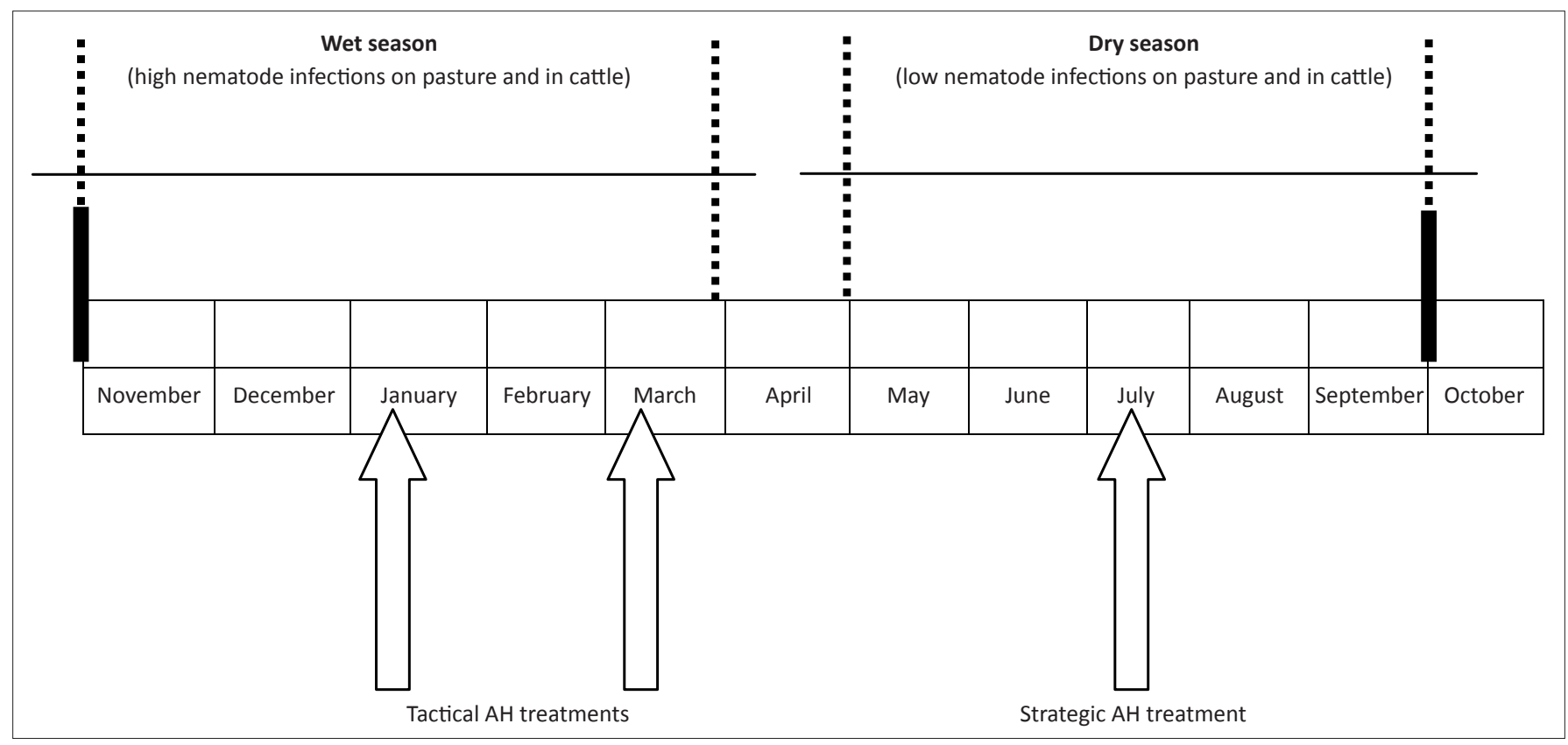

AH, Anthelmintic.

FIGURE 1: Seasonal occurrence of gastrointestinal nematode infections in cattle in Zimbabwe based on epidemiological reports and the recommended treatment options.

day (Van Wyk 1990). Van Wyk (1990) recommended that in general, it is advisable to treat tactically after good rains have fallen over a period of 15 to 30 days and this should commence about three to six weeks after the start of the good rains. Hence, if infection, particularly with adult $H$. placei is severe from January to April, treatments with narrowspectrum anthelmintics (closantel) that are effective against this species should be done. A strategic treatment with a broad-spectrum AH that is effective against arrested H. placei larvae and that has an extended effect against adult Cooperia species and Trichostrongylus species should be administered in July (Figure 1). Such tactical and strategic AH treatments are cost-effective parasite control in Zimbabwe (Duncan \& Forbes 1992; Vassilev 1993; Magaya et al. 2000; Moyo et al. 2003). However, in the communal areas it is imperative that the tactical and strategic $\mathrm{AH}$ treatments are village-based as cattle are communally grazed and there is no benefit for only a few to carry out the recommended control measures. By utilising the dipping facilities, the $\mathrm{AH}$ treatments should be organised and preferably done at the same time within a village.

One of the major constraints with tactical or strategic singledose treatments is the labour involved in gathering and handling cattle, particularly in communal areas where animalhandling facilities are limited. The use of products with persistent action, particularly the MLs, should be encouraged to reduce the frequency of $\mathrm{AH}$ treatments. For ease of use and convenience, pour-on products are now widespread and pour-on ML products are now dominant in the cattle $\mathrm{AH}$ market. Furthermore, one of the other developments is the introduction of controlled release devices (boluses), which deliver anthelmintics either continuously or at targeted times. This offers the possibility of a single-dose treatment without re-course to further treatment and should be used in communal areas during dipping sessions.
Despite the acceptable performance of grazing cattle after $\mathrm{AH}$ treatment, populations of nematodes that are resistant to the most commonly used $\mathrm{AH}$ increasingly threaten this control (Sutherland \& Leathwick 2011). Although AH resistance of cattle nematodes has appeared to develop more slowly than those of small ruminants, literature suggests a rapidly escalating problem with 145 documented cases of AH resistance (Sutherland \& Leathwick 2011). A review by Sutherland and Leathwick (2011) showed reports of AH resistance of cattle nematodes in Argentina, Australia, Brazil, Belgium, UK, Germany, India, New Zealand and USA. This involves all three of the broad-spectrum $\mathrm{AH}$ classes and at least ten species of nematodes. There is no literature about $\mathrm{AH}$ resistance of cattle nematodes in Zimbabwe. However, BZ-resistant Cooperia species and $H$. contortus have been reported in sheep (Boersema \& Pandey 1997; Mukaratirwa, Charakupa \& Hove 1997). Given the rapid increase of reports in the literature about $\mathrm{AH}$ resistance of cattle nematodes, it is important that preventive $\mathrm{AH}$ treatments are integrated in the grazing management system to prevent under-treatment or over-treatment (Vercruysse \& Claerebout 2001). There is also a pressing requirement to determine the extent of the problem in Zimbabwe and other regional countries, as early detection of $\mathrm{AH}$ resistance is an important factor for sustainable chemical control.

\section{Pasture management, biological control and nutrient supplementation}

Pasture spelling and rotational grazing are both means of producing safe pastures and reducing the infectivity of the pasture, especially for more susceptible groups of animals (Morley \& Donald 1980). Survival times of infective larvae of up to nine months in temperate countries are often much longer than the generally accepted limits of up to eight weeks with pasture spelling (Brundson 1980). However, 
relatively shorter survival times of 12 to 16 weeks for $\mathrm{L}_{3}$ bovine strongylids tend to occur in tropical countries (Fabiyi, Copeman \& Hutchinson 1988; Waruiru et al. 1998). Factors that favour worm control by pasture spelling under extensive conditions include low and very erratic rainfall leading to slow pasture growth and sparser plant cover (Van Wyk 1990). Hence, the rapid decline in larval populations that have been noted in tropical climates could make rotational control, based on changing pasture, practicable. This is applicable in the more extensive commercial farming systems of the lowveld region of Zimbabwe, where rainfall is low and very erratic and temperatures are high. Under these conditions, the free-living stages of the worms are more exposed to adverse climatic conditions and can be expected to succumb sooner than when under more intensive conditions (Van Wyk 1990). It is, however, important to note that rotational grazing systems may return animals to a much higher rather than a reduced level of pasture infection (Brundson 1980). Under such circumstances, tactical treatment of the animals is recommended. However, in communal grazing systems, cattle are communally grazed and therefore practices such as rotational grazing and provision of clean pastures would not be feasible.

Practically no cross-transmission between sheep and cattle occur for Oesophagostomum and Bunostomum species (Porter 1953; Rose 1968; Barger \& Southcott 1975; Southcott \& Barger 1975). The two genera are important in Zimbabwe and hence, the alteration of cattle and sheep could be an effective method for controlling these parasites in the country. However, species of Cooperia and intestinal Trichostrongylus can reproduce in the alternate host (Porter 1953; Rose 1968). Cross-transmission of $T$. axei, equally pathogenic to sheep and cattle, is sufficiently effective that alternate grazing of these hosts at intervals of several months has nothing to offer in its control (Kates \& Turner 1960). Furthermore, alternate grazing of the most susceptible hosts (young sheep and young cattle) is not reliable to aid control of Haemonchus species in either host (Morley \& Donald 1980). Hence, cross-transmission between sheep and cattle appears not to be sufficiently restricted, so that alternate grazing would offer substantial benefits in GI nematode control in Zimbabwe, where the dominant parasites are H. contortus and Trichostrongylus species in sheep, and Cooperia species., H. placei and T. axei in cattle.

Older animals are generally more resistant to GI nematode infections than younger animals. An alternate grazing system through rotational grazing of paddocks by calves ahead of cows or heifers could be employed (Morley \& Donald 1980). Two further refinements are the so-called 'forwards creep grazing' whereby calves are grazed ahead of their dams, which follow them directly on the same pasture and 'sideways creep grazing', in which young animals have access to adjacent pasture that is not accessible to their dams (Van Wyk 1990). All forms can be used to control cattle GI nematode infections in the intensive and extensive commercial farming systems of the highveld and lowveld regions of Zimbabwe. However, the system is managerially complex and therefore relatively difficult to apply (Van Wyk 1990) and is not feasible in the communal grazing areas of the country. In addition, one consequence of mixed or alternate grazing of different age groups of cattle is the exposure of older animals to higher levels of larval intake than they might otherwise experience (Morley \& Donald 1980). Except for O. ostertagi where it could lead to the accumulation of very large numbers of arrested larvae in heifers or cows leading to Type II ostertagiosis (Morley \& Donald 1980), this may not be important for most genera in Zimbabwe.

Crop aftermaths (stubble lands) can also be used as safe grazing during the dry season in all the cattle farming systems in Zimbabwe and such aftermaths are practical for worm control (Morley \& Donald 1980; Van Wyk 1990). They are seldom sufficient to accommodate all the susceptible animals and this also requires careful planning to have pasture available in appropriate quantity and quality (Van Wyk 1990).

Biological control includes the use of predatory fungi to kill a variety of nematode species and substantially reduce the intensity of infection (Larsen 1999). With regard to the effect of nematophagous fungi against cattle parasitic nematodes, it is possible to reduce the number of infective larvae on herbage and subsequently to reduce the number of nematodes establishing in the grazing animals (Wolstrup et al. 1994; Larsen et al. 1995; Nansen et al. 1995). Challenges to fungal control are a requirement for daily administering of fungi to the host and achieving the required fungal density inside the dung. However, a nematode-killing fungus, Duddingtonia flagrans, discovered in New Zealand (Skipp et al. 2002), showed a trapping efficiency rate of $78 \%$ and activity for up to 90 days on pasture, providing a viable alternative to reduce animal mortality from nematode infections (Waghorn et al. 2003). Surveys in neighbouring South Africa have shown the presence of local strains of D. flagrans (Durand et al. 2005). Given the limited genetic variation between isolates from different parts of the world (Faedo 2001), a survey of Zimbabwean local strains would address any concerns regarding importing a foreign fungus. When this control approach becomes available for general application, it might be feasible in the small-scale commercial sector, but impractical in the communal set-up.

Plants or crops with natural anti-parasitic properties may play a role in future grazing systems for livestock (Waller \& Thamsborg 2004). Several tannin-containing forages, in particular those with condensed tannins (CT), showed AH activity against GI nematodes of sheep and goats (Hoste et al. 2006). Extracts of three tannin-containing plants, Onobrychis viciifolia, Lotus pedunculatus and Lotus corniculatus, were shown to have in vitro $\mathrm{AH}$ activity against the cattle nematodes O. ostertagi and C. oncophora, with L. pedunculatus tannins being more active than those of $O$. viciifolia and $L$. corniculatus (Novobilsky, Mueller-Harvey \& Thamsborg 
2011). In Zimbabwe, Acacia karoo was shown to have a negative influence on the establishment and fecundity of $H$. contortus infection in Boar goats in comparison to goats fed Acacia nilotica and a basal diet (Kahiya, Mukaratirwa \& Thamsborg 2003). This was attributed to the high content of $\mathrm{CT}$ in $A$. karoo. Further studies are required to determine the $\mathrm{AH}$ effects of tanniniferous plants on cattle GI nematodes and their use in helminth control in order to address the wide problem of $\mathrm{AH}$ resistance.

Well-nourished animals are generally more resistant to the effects of parasite infection. Therefore, nutritional supplementation may reduce the requirement for $\mathrm{AH}$ control (Knox, Torres-Acosta \& Aguilar-Caballero 2006; TorresAcosta et al. 2004). Additional dietary protein (Torres-Acosta et al. 2004), selenium (Au Yeung et al. 2005; Smith et al. 2005), as well as minerals (Islam et al. 2006; Koski \& Scott 2003) may each play a role in countering infections presumably through mechanisms such as enhancing host immunity or maintaining digestive tract integrity.

\section{Host resistance}

Increasingly attractive alternatives for the control of GI nematodes in cattle are the identification of the host genes that influence the acquired or innate resistance to the parasites and the use of the vast potential of the host genome to reduce parasite transmission in cattle populations (Gasbarre et al. 2001). Studies in the USA demonstrated that the number of nematode eggs per gram (EPG) in faeces of pastured cattle is strongly influenced by host genetics (Leighton, Murrell \& Gasbarre 1989) and that the heritability of this trait is approximately 0.30 (Gasbarre, Leighton \& Davies 1990). However, this value is slightly higher than that reported in Africa (Zinsstag et al. 2000). In addition, EPG values are not normally distributed and a small percentage of a herd is responsible for the majority of parasite transmission (Gasbarre et al. 1990). In this over-dispersed distribution, most individuals have relatively low faecal EPG values. A small percentage of animals, estimated to be between $15 \%$ and $25 \%$ of the total population (Anderson \& May 1985), exhibit high EPG values. Furthermore, the odds of certain bulls producing susceptible (high EPG) calves was shown to be 20 times greater than in other bulls (Gasbarre, Leighton \& Bryant 1995). This suggests that genetic management of a small percentage of the herd could considerably reduce overall parasite transmission. Hence, initiation of a selective-breeding programme has revealed that calves can be separated into three types (Gasbarre et al. 2001). Type I or innately immune calves, which never showed high EPG values; Type II or acquired immune calves, which showed rises in EPG values through the first two months on pasture and then fell and remained at levels associated with Type I calves; Type III or immunologically non-responsive calves, which maintained high EPG levels. The approximate percentage ratio of these calves is $25 \% ; 50 \%$ and $25 \%$, respectively. Hence, according to Gasbarre et al. (2001), accurate identification of the genes that control resistance will offer the producer several alternatives for disease control. The small percentage of susceptible animals can be targeted for drug administration and this approach would reduce both the cost of the anthelmintics that are used and the odds for selection of drug-resistant mutants. A second option would be to target susceptible animals for immunotherapy, which would involve vaccines of immunomodulation. A final option would be genetic selection to remove susceptible animals from the herd. Thus, studies on cattle genetics for resistance are required in the country.

\section{Vaccination}

Vaccinations would prevent rather than cure infections and represent a more sustainable and environmentally friendly form of parasitic control compared to drugs. However, with the exception of the vaccine against $D$. viviparus, no vaccines are currently available commercially for the control of helminth infections in ruminants (Knox et al. 2001). Few of the experimental vaccines have proceeded to or successfully passed the next phase of development, which is the largescale, cost-effective production of the vaccine (Geldhof et al. 2007; Redmond \& Knox 2006). Hence, vaccines against parasites are unlikely to become available for the control of worms on farms within the next decade. However, a vaccine for the control of Haemonchus species in sheep and cattle may be the exception (Bassetto et al. 2010). Dairy calves vaccinated three times with a gut membrane from $H$. contortus immunogen and then challenged with $H$. contortus and $H$. placei showed a significant reduction of egg counts for $H$. contortus $(100.0 \%)$ and reduction in worm count for $H$. placei (68.4\%) (Bassetto et al. 2010).

\section{Conclusion}

Nineteen GI nematode species that belong to seven families have been found to occur in cattle in Zimbabwe. Cooperia pectinata, C. punctata, $H$. placei and T. axei are the dominant species. Production and husbandry practices, season, host-age and environment are considered to be the main factors that influence GI nematode infection in cattle in this country. Based on current epidemiological information, wellorganised national preventive treatment strategies should be employed to control GI nematode infections in cattle. A broad-spectrum AH administered tactically in January and March would control immature and adult forms of H. placei, O. radiatum, Cooperia species and Trichostrongylus species. It is recommended that a strategic treatment with a broadspectrum $\mathrm{AH}$ that is effective against arrested $H$. placei larvae and that also has an extended effect against adult Cooperia species and Trichostrongylus species should be administered in July.

\section{Acknowledgements Competing interests}

The authors declare that they have no financial or personal relationship(s) that may have inappropriately influenced them in writing this article. 


\section{Authors' contributions}

D.M.P. (University of KwaZulu-Natal) a postdoctoral fellow in 2012 and S.M. (University of KwaZulu-Natal) contributed equally in conceptualising and writing this article.

\section{References}

Agneessens, J., Claerebout, E. \& Vercruysse, J., 2001, 'Development of a copro-antigen capture ELISA for detecting Ostertagia ostertagi infections in cattle', Veterinar Parasitology 97, 227-238. http://dx.doi.org/10.1016/S0304-4017(01)00398-3

Amarante, A.F.T, Bagnola JR, J., Amarante, M.R.V. \& Barbosa, M.A., 1997, 'Host specificity of sheep and cattle nematodes in Sao Paulo State, Brazil', Veterinary Parasitology 73, 89-104. http://dx.doi.org/10.1016/S0304-4017(97)00036-8

Anderson, R.M. \& May, R.M., 1985, 'Herd immunity to helminth infection and implications for parasite control', Nature 315, 493-496. http://dx.doi. implications for parasite control,

Anderson, N., Armour, J., Jarrett, W.F., Jennings, F.W., Ritchie, J.S. \& Urquhart, G.M., 1965, 'A field study of parasitic gastritis in cattle', Veterinary Record 77, 11961204. http://dx.doi.org/10.1136/vr.77.41.1196, PMid:5890703

Au Yeung, K.J., Smith, A., Zhao, A., Madden, K.B., Elfrey, J., Sullivan, C. et al., 2005, 'Impact of vitamin E or selenium deficiency on nematode-induced alterations in murine intestinal function', Experimental Parasitology 109, 201-208. http:// dx.doi.org/10.1016/j.exppara.2004.12.015, PMid:15755417

Barger, I.A. \& Southcott, W.H., 1975, 'Control of nematode parasites by grazing management-I. Decontamination of cattle pastures by grazing with sheep', International Journal for Parasitology 5, 39-44. http://dx.doi.org/10.1016/00207519(75)90095-8

Bassetto, C.C., Silva, B.F., Carvalho, C.O., Xavier, J.K., Smith, W.D. \& Amarante, A.F.T. 2010, 'Protection of cattle against Haemonchus placei and Haemonchus contortus after immunization with gut membrane proteins of $H$. contortus', Parasite Immunology 33, 377-381. http://dx.doi.org/10.1111/j.1365-3024.2011.01295.x PMid:21535018

Berghen, P., Hilderson, H., Vercrruysse, J. \& Dorny, P., 1993, 'Evaluation of pepsinogen gastrin and antibody response in diagnosing ostertagiosis', Veterinary Parasitology 46, 175-195. http://dx.doi.org/10.1016/0304-4017(93)90057-T

Bevan, L.E.W., 1929, 'Notes from the Veterinary Laboratory: Parasitic gastritis', Rhodesian Agricultural Journal 26, 981-994.

Bevan, L.E.W., 1930, 'Notes from the Veterinary Laboratory: Diseases of domestic animals', Rhodesian Agricultural Journal 27, 709-721.

Bianchin, I. \& Honer, M.R., 1987, 'Helminth parasites of beef cattle in the Cerrado Region of Brazil', Tropical Animal Health and Production 19, 39-45. http://dx.doi. org/10.1007/BF02250844, PMid:3603712

Boersema, J.H. \& Pandey, V.S., 1997, 'Anthelmintic resistance of trichostrongylids in sheep in the highveld of Zimbabwe', Veterinary Parasitology 68, 383-388. http:// dx.doi.org/10.1016/S0304-4017(96)01089-8

Boomker, J. Du Plessis, W.H. \& Boomker, E.A., 1983, 'Some helminth and arthropod parasites of the grey duiker, Sylvicapra grimmia', Onderstepoort Journal of Veterinary Research 50, 233-241. PMid:6676685

Boomker, J., Keep, M.E., Flamand, J.R. \& Horak, I.G., 1984, 'The helminths of various antelope species from Natal', Onderstepoort Journal of Veterinary Research 51 253-256. PMid:6241958

Brundson, R.V., 1980, 'Principles of helminth control', Veterinary Parasitology 6, 185215. http://dx.doi.org/10.1016/0304-4017(80)90043-6

Bryant, B.A. \& Norval, R.A.I., 1985, 'Diseases affecting domestic animals in communal lands in Mashonaland', Zimbabwe Veterinary Journal 16, 9-17.

Buckley, J.J.C., 1933, 'Some helminth parasites from domesticated animals in Southern Rhodesia', Journal of Helminthology 11, 109-114. http://dx.doi.org/10.1017/ S0022149X00001759

Charlier, J., Höglund, J., Samson-Himmelstjerna, G., Dorny, P. \& Vercruysse, J., 2009, "Gastrointestinal nematode infections in adult dairy cattle: Impact on production, diagnosis and control', Veterinary Parasitology 164, 70-79. http://dx.doi. org/10.1016/j.vetpar.2009.04.012, PMid:19414223

Chiejina, S.N., 1994, 'Epidemiology of some helminth infections of domesticated animals in the tropics with emphasis on fasciolosis and parasitic gastroenteritis' in Helminthology, edited by N. Chowdhury \& I. Tada. Springer-Verlag, Narosa Publishing House, New Delhi: 34-72. http://dx.doi.org/10.1007/978-3-642 78838-3_2

Condy, J.B., 1972, 'Observations on the levels of internal parasites in free-living Rhodesian wildlife. 1. Kudu (Tragelaphus strepsiceros) (Pallas, 1766)', Zoologica Africana 7, 413-418.

Christie, G.J., 1957, 'Report of the Secretary of the Federal Ministry of Agriculture' Southern Rhodesia, for the year ending $30^{\text {th }}$ September, 1957.

Dimander, S.O., Hoglund, J., Sporndly, E. \& Waller, P.J., 2000, 'The impact of internal parasites on the productivity of young cattle organically reared on semi-natura pastures in Sweden', Veterinary Parasitology 90, 271-284. http://dx.doi. org/10.1016/S0304-4017(00)00256-9

Dimander, S.O., Hoglund, J., Uggla, A., Sporndly, E. \& Waller, P.J., 2003, 'Evaluation of gastrointestinal nematode parasite control strategies for first-season grazing cattle in Sweden', Veterinary Parasitology 111, 193-209. http://dx.doi.org/10.1016/ S0304-4017(02)00380-1
Duncan, I.M. \& Forbes, A.B., 1992, 'Comparison of productivity and economic benefits of strategic anthelmintic use in young beef cattle in Zimbabwe', Zimbabwe Veterinary Journal 23, 93-99.

Durand, D.T., Boshoff, S.H., Michael, L.M. \& Krecek, R.C., 2005, 'Survey of nematophagous fungi in South Africa', Onderstepoort Journal of Veterinary Research 72, 185-187. http://dx.doi.org/10.4102/ojvr.v72i2.217, PMid:16137137

Durie, P.H., 1962, 'Parasitic gastroenteritis of cattle: seasonal fluctuations of populations of strongyle larvae on a calf pasture and their significance in infection of the grazing animal', Australian Journal of Agricultural Research 13, 767-777. http://dx.doi.org/10.1071/AR9620767

Eysker, M. \& Pandey, V.S., 1991, 'The epidemiology of gastrointestinal nematode infections of beef cattle in the highveld of Zimbabwe', in Proceedings of Southern
Conference on Avian Diseases and Southern Conference on Animal Parasites, Conference on Avian Diseases and Southern Conference on An
College of Veterinary Medicine, Auburn, AL, USA, abstracts p. 40.

Eysker, M., Jansen, J. \& Pandey, V.S., 1990, 'Epidemiology of gastrointestinal helminth infections of cattle in Zimbabwe', in Proceedings of the $1^{\text {st }}$ Tropical Animal Health and Production Symposium, Utrecht University, Netherlands, pp. 36-37.

Fabiyi, J.P., Copeman, D.B. \& Hutchinson, G.W., 1988, 'Abundance and survival of infective larvae of the cattle nematodes Cooperia punctata, Haemonchus placeiand Oesophagostomum radiatum from faecal pats in a wet tropical climate', Australian Veterinary Journal 65, 229-231. http://dx.doi.org/10.1111/j.1751-0813.1988. tb14305.x, PMid:3190586

Faedo, M., 2001, 'Growth, trapping and genetic diversity of Duddingtonia flagrans-a biological control agent free-living larval stages of ruminant parasitic nematodes'. $\mathrm{PhD}$ thesis, Danish Centre for Experimental Parasitology, The Royal Veterinary and Agricultural University, Denmark.

Forbes, A.B., Huckle, C.A., Gibb, M.J., Rook, A.J. \& Nuthall, R., 2000, 'Evaluation of the effects of nematode parasitism on grazing behaviour, herbage intake and growth in young grazing cattle', Veterinary Parasitology 90, 111-118. http://dx.doi. org/10.1016/S0304-4017(00)00218-1

Fox, M.T., 1993, 'Pathophysiology of infection with Ostertagia ostertagi in cattle', Veterinary Parasitology 46, 143-158. http://dx.doi.org/10.1016/03044017(93)90055-R

Gasbarre, L.C. \& Canals, A., 1989, 'Induction of protective immunity in calves immunized with adult Oesophagostomum radiatum somatic antigens', Veterinary Parasitology 34, 223-238. http://dx.doi.org/10.1016/0304-4017(89)90053-8

Gasbarre, L.C., Leighton, E.A. \& Davies, C.J., 1990, 'Genetic control of immunity to gastrointestinal nematodes of cattle', Veterinary Parasitology 37, 257-272. http:// dx.doi.org/10.1016/0304-4017(90)90009-Z

Gasbarre, L.C., Leighton, E.A. \& Bryant, D., 1995, 'Genetically controlled resistance to gastrointestinal nematode infections of cattle', Proceedings of Beef Improvement Federation, 212-217.

Gasbarre, L.C., Leighton, E.A. \& Sonstergard, T., 2001, 'Role of the bovine immune system and genome in resistance to gastrointestinal nematodes', Veterinary Parasitology 98, 51-64. http://dx.doi.org/10.1016/S0304-4017(01)00423-X

Gatongi, P.M., Gathuma, J.M. \& Munyua, W.K., 1987, 'The prevalence of gastrointestinal nematodes in cattle in Tetu Division of Nyeri District, Kenya', Bulletin of Animal Health and Production in Africa 35, 294-297.

Geldhof, P., Clark, D., Molloy, C. \& Knox, D.P., 2007, 'Assessment of Caenorhabditis elegans as a model in Haemonchus contortus vaccine research', Molecular Biochemistry and Parasitology 152, 220-223. http://dx.doi.org/10.1016/j. molbiopara.2006.12.006, PMid:17234278

Grant, J.L., 1973, 'A study of nematode parasites in sheep', M.Phil. Thesis, University of London.

Grobler, J.H., 1981, 'Parasites and mortality of sable antelope, Hippotragus niger niger (Harris, 1938) in the Matopos, Zimbabwe', Koedoe 24, 119-123.

Gross, S.J., Ryan, W.G. \& Ploeger, H.W., 1999, 'Anthelmintic treatment of dairy cows and its effect on milk production', Veterinary Record 144, 581-587. http://dx.doi. org/10.1136/vr.144.21.581, PMid:10378289

Guitian, FJ. Dohoo, I.R. Markham, R.J.F. Conboy, G. \& Keefe, G.P. 2000 'Relationships between bulk-tank antibodies to Ostertagia ostertagi and herdmanagement practices and measures of milk production in Nova Scotia dairy
herds', Preventive Veterinary Medicine 47, 79-89. http://dx.doi.org/10.1016/ herds', Preventive Veterina
S0167-5877(00)00156-2

Hawkins, J.A., 1993, 'Economic-benefits of parasite control in cattle', Veterinary Parasitology 46, 159-173. http://dx.doi.org/10.1016/0304-4017(93)90056-S

Hilderson, H., Vercruysse, J., Berghen, P., Dorny, P. \& McKellar, Q.A., 1992, 'Diagnostic value of gastrin for clinical bovine ostertagiosis', Journal of Veterinary Medicine $B \quad 39,187-192$. http://dx.doi.org/10.1111/j.1439-0450.1992.tb01157.x PMid:1642075

Horak, I.G., 1980, 'The control of parasites in antelope in small game reserves', Journal of the South African Veterinary Association 51, 17-19. PMid:7452652

Horak, I.G., 1981, 'The seasonal incidence of the major nematode genera recovered from sheep, cattle, impala and blesbok in the Transvaal', Journal of the South African Veterinary Association 52, 213-223. PMid:7198149

Horak, I.G., Evans, U. \& Purnell, R.E., 2004, 'Parasites of domestic and wild animals in South Africa. XLV. Helminths of dairy calves on dry-land Kikuyu grass pastures in the Eastern Cape Province', Onderstepoort Journal of Veterinary Research 71 291-306. http://dx.doi.org/10.4102/ojvr.v71i4.249, PMid:15732456

Hoste, H., Jackson, F., Athanasiadou, S., Thamsborg, S.M. \& Hoskin, S.O., 2006, 'The effects of tannin-rich plants on parasitic nematodes in ruminants', Trends in Parasitology 22, 253-261. http://dx.doi.org/10.1016/j.pt.2006.04.004 PMid:16632404

Islam, M.K., Miyoshi, T., Yamada, M., Alim, M.A., Huang, X., Motobu, M. et al., 2006, 'Fluoride exposure inhibits protein expression and enzyme activity in the lung-stage larvae of Ascaris suum', Parasitology 133, 497-508. http://dx.doi. org/10.1017/S0031182006000576, PMid:16959050 
Jooste, R., 1984, 'Internal parasites of wild-life in Zimbabwe: Blue Duiker (Cephalophus monticola fusicolor Blaine, 1922)', Zimbabwe Veterinary Journal 15, 32-33.

Jooste, R., 1987, 'Internal parasites of wild-life in Zimbabwe: Impala (Aepyceros melampus)', Zimbabwe Veterinary Journal 18, 44-55.

Jooste, R., 1989, 'A checklist of the helminth parasites from the larger domestic and wild mammals of Zimbabwe', Transactions of the Zimbabwe Science Association 64, 15-32.

Kahiya, C., Mukaratirwa, S. \& Thamsborg, S.M., 2003, 'Effects of Acacia nilotica and Acacia karoo diets on Haemonchus contortus infection in goats', Veterinar Parasitology 115, 265-274. http://dx.doi.org/10.1016/S0304-4017(03)00213-9

Kates, K.C. \& Turner, J.H., 1960, 'Experimental trichostrongylosis (axei) in lambs, with a discussion of recent research on this disease in ruminants', American Journal of Veterinary Research 21, 254-261. PMid:14404716

Kloosterman, A., Ploeger, H.W., Pieke, E.J., Lam, T.J.G.M. \& Verhoeff, J., 1996, 'The value of bulk milk ELISA Ostertagia antibody titres as indicators of milk production response to anthelmintic treatment in the dry period', Veterinary Parasitology 64 197-205. http://dx.doi.org/10.1016/0304-4017(95)00919-1

Knottenbelt, M.K., 1989, 'Control of helminths in wildlife in Zimbabwe', Zimbabwe Veterinary Journal 20, 1-10.

Knottenbelt, M.K., 1990, 'Causes of mortality in impala (Aepyceros melampus) on 20 game farms in Zimbabwe', Veterinary Record 127, 282-285. PMid:2238405

Knox, D.P., Redmond, D.L., Skuce, P.J. \& Newlands, G.F., 2001, 'The contribution of molecular biology to the development of vaccines against nematode and trematode parasites of domestic ruminants', Veterinary Parasitology 22, 311-335. http://dx.doi.org/10.1016/S0304-4017(01)00558-1

Knox, M.R., Torres-Acosta, J.F.J. \& Aguilar-Caballero, A.J., 2006, 'Exploiting the effect of dietary supplementation of small ruminants on resilience and resistance against gastrointestinal nematodes', Veterinary Parasitolog $139 \quad 385-393 . \quad \mathrm{http} / / / \mathrm{dx}$. doi.org/10.1016/j.vetpar.2006.04.026 Koski, K.G. \& Scott, M.E., 2003, 'Gastrointestinal nematodes, trace elements and immunity', Journal of Trace Elements and Experimental Medicine 16, 237-251. http://dx.doi.org/10.1002/jtra.10043

Larsen, M., 1999, 'Biological control of helminths', International Journal for Parasitology 29, 139-146. http://dx.doi.org/10.1016/S0020-7519(98)00185-4

Larsen, M., Nansen, P., Wolstrup, J., Gronvold, J., Henriksen, S.A. \& Zorn, A., 1995 'Biological control of trichostrongyles in calves by the fungus Duddingtonia flagrans fed to animals under natural grazing conditions', Veterinary Parasitology flagrans fed to animals under natural grazing conditions', Veterin

Larsson, A., Dimander, S.O., Rydzik, A., Uggla, A., Waller, P.J. \& Hoglund, J., 2006, 'A 3-year field evaluation of pasture rotation and supplementary feeding to control parasites in first-season grazing cattle - effects on animal performance', Veterinary Parasitology 142, 197-206. http://dx.doi.org/10.1016/j.vetpar.2006.07.017, PMid:16971047

Lawrence, D.A., 1928, 'Report of the director of Veterinary Research of Southern Rhodesia for the year ending 30th September 1928', Central Veterinary Laboratory, Harare, Zimbabwe.

Leathwick, D.M., Waghorn, T.S., Miller, C.M., Atkinson, D.S., Haack, N.A. \& Oliver, A.M., 2006, 'Selective and on demand drenching of lambs: Impact on parasite populations and performance of lambs', New Zealand Veterinary Journal 54, 305312. http://dx.doi.org/10.1080/00480169.2006.36715, PMid:17151729

Leighton, E.A., Murrell, K.D. \& Gasbarre, L.C., 1989, 'Evidence for genetic control of nematode egg-shedding rates in calves', Journal of Parasitology 75, 498-504. http://dx.doi.org/10.2307/3282895, PMid:2760760

Levine, N.D., 1963, 'Weather, climate and the bionomics of ruminant nematode larvae', Advances in Veterinary Science 8, 215-261.

Lima, W.S., 1998, 'Seasonal infection pattern of gastrointestinal nematodes of beef cattle in Minas Gerais State-Brazil', Veterinary Parasitology 74, 203-214. http:// dx.doi.org/10.1016/S0304-4017(97)00164-7

Louw, J.P., 1999, 'The helminths of ranch calves in the North-eastern Mountain Grassland of South Africa', Onderstepoort Journal of Veterinary Research 66, 335-338. PMid:10689707

Madzingira, O. \& Mukaratirwa, S., 2002, 'Helminth parasites of antelope in Zimbabwe: An update', Zimbabwe Veterinary Journal 33, 109-115.

Madzingira, O., Mukaratirwa, S., Pandey, V.S. \& Dorny, P., 2002a, 'A questionnaire survey of the management and use of anthelmintics in cattle and antelope in mixed farming systems in Zimbabwe', Journal of the South African Veterinary Association 73, 70-73. http://dx.doi.org/10.4102/jsava.v73i2.559, PMid:12240773

Madzingira, O., Mukaratirwa, S., Pandey, V.S. \& Dorny, P., 2002b, 'Helminth parasites of cattle and antelope in a mixed farming system in Zimbabwe', in The Tenth International Congress of Parasitology, Vancouver, Canada, pp. 627-637.

Magaya, A., Mukaratirwa, S., Mutisi, C., Kyvsgaard, N. \& Thamsborg, S., 2000, 'Effects of fenbendazole slow-release (sr) bolus on productivity of indigenous cattle on communal pasture in Sanyati area, Zimbabwe', Zimbabwe Veterinary Journal 31 29-40.

Malan, F.S., Van Wyk, J.A. \& Wessels, C.D., 2001, 'Clinical evaluation of anaemia in sheep: early trials', Onderstepoort Journal of Veterinary Research 61, 165-174.

Morley, F.H.W. \& Donald, A.D., 1980, 'Farm management and systems of helminth control', Veterinary Parasitology 6, 105-134. http://dx.doi.org/10.1016/03044017(80)90040-0

Moyo, D.Z., Bwangamoi, O., Hendrikx, W.M.L. \& Eysker, M., 1996, 'The epidemiology of gastrointestinal nematode infections in communal cattle and commercial beef cattle on the highveld of Zimbabwe', Veterinary Parasitology 67, 105-120. http:// dx.doi.org/10.1016/S0304-4017(96)01030-8
Moyo, D.Z., Eysker, M., Hendrikx, W.M.L., Bwangamoi, O. \& Obwolo, M.J., 1997 'Ostertagia ostertagi infection in cattle on an irrigated farm on the highveld of Zimbabwe', Zimbabwe Veterinary Journal 28, 1-5.

Moyo, D.Z., Hendrikx, W.M., Obwolo, M.J. \& Eysker, M., 2003, 'The effect of treatment with a $1 \%$ injectable formulation of moxidectin during the rainy season and at the beginning of the dry season on gastrointestinal nematodes in cattle from communal areas in Zimbabwe', Tropical Animal Health and Production 35, 1-16. http://dx.doi.org/10.1023/A:1022011903760, PMid:12636357

Moyo, D.Z., 2006, 'An abattoir study of prevalence and seasonal fluctuations of gastrointestinal nematodes of cattle in the Midlands Province, Zimbabwe', Research Journal of Animal and Veterinary Sciences 1, 37-40.

Mukaratirwa, S., Charakupa, R. \& Hove, T., 1997, 'A survey of anthelmintic resistance on ten sheep farms in Mashonaland East Province, Zimbabwe', Journal of the South African Veterinary Association 68, 140-143. http://dx.doi.org/10.4102/ jsava.v68i4.896, PMid:9561499

Nansen, P., Larsen, M., Gronvold, J., Wolstrup, J., Zorn, A. \& Henriksen, S.A., 1995 'Prevention of clinical trichostrongylidosis in calves by strategic feeding with the predacious fungus Duddingtonia flagrans', Parasitology Research 81, 371-374. http://dx.doi.org/10.1007/BF00931496, PMid:7501634

Novobilsky, A., Mueller-Harvey, I. \& Thamsborg, S.M., 2011, 'Condensed tannins act against cattle nematodes', Veterinary Parasitology 182, 213-220. http://dx.doi. against cattle nematodes, Veterinary Parasitology
org/10.1016/j.vetpar.2011.06.003, PMid:21726942

Obwolo, M.J., Hill, F.W.G., Nyathi, C.B., Ogaa, J.S., Odiawo, G.O. \& Llwelyn, C.A., 1992, 'Studies on indigenous cattle under traditional management in Zimbabwe: 1 Endoparasites', Zimbabwe Veterinary Journal 23, 101-106.

Obwolo, M.J., Ogaa, J.S., Nyathi, C.B., Majok, A., Hill, F.W.G., Odiawo, G.O. et al. 1995 'Studies of indigenous cattle kept on a paddock rotation system in Zimbabwe', Zimbabwe Veterinary Journal 26, 89-101.

Pandey, V.S., 1989, 'Helminth infections of ruminants in Zimbabwe', in Livestock Production and Diseases in the Tropics, edited by J. Kuil, R.S. Paling \& J.E. Huhn. Faculty of Veterinary Medicine, Utrecht, Netherlands, pp. 203-205.

Pandey, V.S., Nyanzunda, T.M. \& Chitate, F., 1990a, 'Gastro-intestinal nematodes in communal land cattle in Zimbabwe', Bulletin for the Society of French Parasitologists 8 (suppl. 2), 756.

Pandey, V.S., Hill, F.W.G., Hensman, D.S. \& Baragwanath, L.C., 1990b, 'Toxocara vitulorum in beef calves kept on effluent irrigated pastures in Zimbabwe', Veterinary Parasitology 35, 349-355. http://dx.doi.org/10.1016/0304 4017(90)90139-3

Pandey, V.S., Chitate, F. \& Nyanzunda, T.M., 1993, 'Epidemiological observations on gastro-intestinal nematodes in communal land cattle from the highveld of Zimbabwe', Veterinary Parasitology 51, 99-106. http://dx.doi.org/10.1016/03044017(93)90200-7

Pfukenyi, D.M., Mukaratirwa, S., Willingham, A.L. \& Monrad, J., 2007, 'Epidemiological studies of parasitic gastrointestinal nematodes, cestodes and coccidia infections in cattle in the highveld and lowveld communal grazing areas of Zimbabwe Onderstepoort Journal of Veterinary Research 74, 129-142. http://dx.doi. org/10.4102/ojvr.v74i2.132, PMid:17883199

Poot, J., Kooyman, F.N.J., Dop, P.Y., Schallig, H.D.F.H., Eysker, M. \& Cornelissen, A.W.C.A., 1997, 'Use of cloned excretory/secretory low molecular weight proteins of Cooperia oncophora in a serological assay', Journal of Clinical Microbiology 35, 1728-1733. PMid:9196182, PMCid:PMC229830

Porter, D.A., 1953, 'Cross transmission of parasitic worms between sheep and cattle', American Journal of Veterinary Research 14, 550-554. PMid:13092391

Redmond, D.L. \& Knox, D.P., 2006, 'Further protection studies using recombinant forms of Haemonchus contortus cysteine proteinases', Parasite Immunology 28 213-219. http://dx.doi.org/10.1111/j.1365-3024.2006.00823.x, PMid:16629707

Reinecke, R.K., 1960, 'A field study of some nematode parasites of bovines in a semi-arid area, with special reference to their biology and possible methods of prophylaxis', Onderstepoort Journal of Veterinary Research 28, 365-464.

Reinecke, R.K., 1983, 'Veterinary Helminthology', Butterworths Publishers (Pty) Ltd., Durban and Pretoria.

Rivera, B., Parra, D., Garcia, O. \& Aycardi, E., 1983, 'Gastro-intestinal parasites in calves in Columbia', Tropical Animal Health and Production 15, 107-114. http://dx.doi. org/10.1007/BF02239806, PMid:6868130

Rose, J.H., 1968, 'Species of gastrointestinal nematodes of cattle in S.E. England', Veterinary Record 82, 615-617.

Sanchez, J., Nodtvedt, A., Dohoo, I. \& DesCoteaux, L., 2002, 'The effect of eprinomectin treatment at calving on reproduction parameters in adult dairy cows in Canada', Preventive Veterinary Medicine 56, 165-177. http://dx.doi.org/10.1016/S01675877(02)00118-6

Shaw, D.J., Vercruysse, J., Claerebout, E. \& Dorny, P., 1998 ' 'Gastrointestinal nematode infections of first-grazing season calves in Western Europe: general patterns and the effect of chemoprophylaxis', Veterinary Parasitology 75, 115-131. http:// dx.doi.org/10.1016/S0304-4017(97)00214-8

Skipp, R.A., Chen, L.Y., Yeates, G.W. \& Glare, R., 2002, 'Occurrence, morphological characteristics and ribotyping of New Zealand isolates of Duddingtonia flagrans, a candidate for biocontrol of animal parasitic nematodes', New Zealand Journal a candidate for biocontrol of animal parasitic nematodes', New Zealand Journal of Agricultura

Smith, A., Madden, K.B., Yeung, K.J.A., Zhao, A., Elfrey, J., Finkelman, F. et al. 2005 'Deficiencies in selenium and/or vitamin E lower the resistance of mice to Heligmosomoides polygyrus infections', Journal of Nutrition 135, 830-836. PMid:15795443

Southcott, W.H. \& Barger, I.A., 1975, 'Control of nematode parasites by grazing management. II. Decontamination of sheep and cattle pastures by varying periods of grazing with the alternate host', International Journal for Parasitology 5, 45-48. http://dx.doi.org/10.1016/0020-7519(75)90096-X 
Sutherland, I.A. \& Leathwick, D.M., 2011, 'Anthelmintic resistance in nematode parasites of cattle: a global issue?', Trends in Parasitology 27, 176-181. http:// parasites of cattle: a global issue?', Trends in Parasito
dx.doi.org/10.1016/j.pt.2010.11.008, PMid:21168366

Torres-Acosta, J.F.J., Jacobs, D.E., Aguilar-Caballero, A., Sandoval-Castro, C., MayMartinez, M. \& Cob-Galera, L.A., 2004, 'The effect of supplementary feeding on the resilience and resistance of browsing Criollo kids against natural gastrointestinal nematode infections during the rainy season in tropical Mexico', Veterinary Parasitology 124, 217-238. http://dx.doi.org/10.1016/j.vetpar.2004.07.009, PMid:15381302

Tsotetsi, A.M. \& Mbati, P.A., 2003, 'Parasitic helminths of veterinary importance in cattle, sheep and goats on communal farms in the northeastern Free State, South Africa', Journal of the South African Veterinary Association 74, 45-48. http:// dx.doi.org/10.4102/jsava.v74i2.503, PMid:12967050

Van Wyk, J.A., 1990, 'Integrated worm control as a strategy in the control of gastrointestinal nematodes of sheep and cattle', Journal of the South African Veterinary Association 61, 141-145. PMid:2287005

Vassilev, G.D., 1993, 'Activity of ivermectin and albendazole in the control of gastrointestinal nematode parasites and growth performance of two year old beef cattle', Zimbabwe Veterinary Journal 24, 121-148. http://dx.doi.org/10.1016/ S0304-4017(01)00431-9

Vassilev, G.D., 1994, 'Prevalence and seasonality of internal parasite infections detectable by faecal examination of cattle in Chiweshe communal farming area of Zimbabwe', Zimbabwe Veterinary Journal 25, 41-63.

Vassilev, G.D., 1999, 'Prevalence of internal parasite infections of cattle in the communal farming areas of Mashonaland East Province, Zimbabwe', Zimbabwe Veterinary Journal 30, 1-17.

Vercruysse, J. \& Claerebout, E., 2001, 'Treatment vs. non-treatment of helminth infections in cattle: defining the thresholds', Veterinary Parasitology 98, 195-214.
Waghorn, T.S., Leathwick, D.M., Chen, L.Y. \& Skipp, R.A., 2003, 'Efficacy of the nematode-trapping fungus Duddingtonia flagrans against three species of gastro-intestinal nematodes in laboratory faecal cultures from sheep and goats', Veterinary Parasitology 118, 227-234. http://dx.doi.org/10.1016/j. goats', Veterinary Parasitology 118,
vetpar.2003.09.018, PMid:14729170

Waller, P.J. \& Thamsborg, S.M., 2004, 'Nematode control in 'green' ruminant production systems', Trends in Parasitology 20, 493-497. http://dx.doi. org/10.1016/j.pt.2004.07.012, PMid:15363444

Walsh, A., Younis, P.J. \& Morton, J.M., 1995, 'The effect of ivermectin treatment of late pregnant dairy cows in south-west Victoria on subsequent milk production and reproductive performance', Australian Veterinary Journal 72, 201-207. http:// dx.doi.org/10.1111/j.1751-0813.1995.tb03520.x, PMid:8526811

Waruiru, R.M., Munyua, W.K., Thamsborg, S.M., Nansen, P., Bøgh, H.O. \& Gathuma, J.M., 1998, 'Development and survival of infective larvae of gastrointestinal nematodes of cattle on pasture in central Kenya', Veterinary Research Communications 22, 315-323. http://dx.doi.org/10.1023/A:1006112802459, PMid:9778777

Williams, J.C. \& Mayhew, R.L., 1967, 'Survival of infective larvae of the cattle nematodes Cooperia punctata, Trichostrongylus axei and Oesophagostomum radiatum', American Journal of Veterinary Research 28, 629. PMid:6068246

Wolstrup, J., Gronvold, J., Henriksen, S.A., Nansen, P., Larsen, M., Bogh, H.O. et al. 1994, 'An attempt to implement the nematode-trapping fungus Duddingtonia flagrans in biological control of free-living stages of trichostrongyles in first year grazing calves', Journal of Helminthology 68, 175-180. http://dx.doi.org/10.1017/ S0022149X00013729, PMid:7930461

Zinsstag, J., Ankers, P.H., Nije, M., Smith, T., Pandey, V.S., Pfister, K. et al. 2000 'Heritability of gastrointestinal nematode faecal egg counts in West Africa village N'Dama cattle and its relation to age', Veterinary Parasitology 89, 71-78. http:// dx.doi.org/10.1016/S0304-4017(99)00226-5 